\title{
The Phenomenon of Femicide and the Greek Experience
}

\author{
M. Kouroutsidou and S.M.Kakarouna
}

\begin{abstract}
In an effort of definition, femicide refers to the intentional murder of a woman, because she is a woman, or she defines herself as a woman. The term "femicide" was introduced by feminist writer and activist Diana Russell, who used it in the 1970 s to refer, in an alternative way, to the homicide with female victims, giving it a specific meaning. The use of the term by Russell was motivated by the political intention to showcase discriminations, inequalities, and systematic violence against women, which, in extreme cases, leads to their death.
\end{abstract}

Keywords - Femicide, gender-based violence, sexual motives, patriarchical perceptions.

\section{Definition, Causes, Types, Consequences. Why Is It Not A SiMPLE HoMicide?}

The phenomenon of killing a woman or a girl because of her gender is internationally determined by the term femicide or femicidio/feminicidio[1]. The term was used by John Corry [2] in his book A Satirical View of London referring to the murder of a woman. The term was also found in 1840 in legal dictionaries of that period; later it was abandoned [1] to reappear in 1976, when it was used by Diana Russell and other feminists [2].

Femicide is different from homicide because of the murderer's sexist motives. Russell and Radford determined femicide as the murder of women by men due to misogynism, while the phenomenon was acknowledged as a form of sexual violence [3]. Subsequently, femicide was defined as "the murder of one or more women by one or more men, because they are women" [2], [3]. The suggestion to use the term gendercide is rejected by most feminists as, according to [1], it may indicate also murders of men, without taking into account the sexist motives. On the contrary, it is the culmination of multiple and regular previous manifestations of violence, mainly because of the unequal power relationships between women and men and the deeply rooted stereotype of patriarchal perception, which gives men the right of corrective punishment of women, even by means of their death.

\section{TYPES OF FEMICIDES}

There are several types of femicides. Indicatively, the following ones can be mentioned:

a. Murder of a woman committed by her (current or ex)

Published on September 21, 2020

M. Kouroutsidou, Department of Nursery Education and Education

Design Sciences, University of the Aegean, Greece.

(corresponding e-mail: kouroutsidou@aegean.gr)

S.M.Kakarouna, University of the Aegean, Greece.

(e-mail: psemnem@aegean.gr) partner, known as intimate femicide [4]. The rate of such murders corresponds to $35 \%$ of all femicides globally and confirms that home, the place that is supposed to offer safety to women, becomes the place of their violent killing [1],

b. Murders in the name of 'honor'. The victim of such murders is a woman, or a girl killed by a member of her family for an actual or assumed sexual intercourse, e.g., adultery or pregnancy outside marriage. The aggressors commit the crime because they believe that in this way they protect family reputation, within the context of religious and cultural traditions, while often such murders cover up cases of incest [5]. Approximately 5,000 murders in the name of 'honor' are committed every year worldwide, mainly in Middle East and South Asia $^{1}$,

c. Murders linked to cultural traditions and especially dowry, involving mainly in-laws killing newly married women because of conflicts related to dowry. Such incidents occur in the broader area of India [4],

d. Non-intimate femicide, namely femicide committed in a non-intimate, external environment by someone without an intimate relationship with the victim. This type of femicide is related to sexual terrorism and is sometimes described as "sexual femicide", while it can take the form of serial femicide. Such murders are committed particularly in Latin America [1],[4] underlines the involvement of gender in social class, race, and gender identity and therefore the racist motive, intersecting the sexist one, which, precisely because of its marginalized nature, leaves the police authorities almost indifferent.Finally, it is worth mentioning as a special case of femicide the female infanticide, which designates the killing of female fetuses or newborn female children because of their gender [1].

\section{RELATIONSHIPS BETWEEN ViCTIM AND MURDERER, Motives, Role of THE DifFerent Legal Systems IN DEALING WITH IT}

The study of literature shows that femicide is usually committed by men, but sometimes female members of the family may also be involved. Regarding the relationship between murderer and victims, research shows that most murders are committed by familiar people, partners, or members of the victims' family [7]. More specifically, when

${ }^{1}$ At level of continents, high rates of murdered women are observed in descending order in Asia, Africa, America, Europe, and Oceania, while the available international data confirm that the highest percentage of such murders occur in the family environment, with Africa taking the lead; in Africa, women are at higher risk than in any other continent to be murdered by a member of their family [6]. 
it comes to ex and current partners, it seems to be the ending of a long abusive and violent relationship. The motives of a femicide are primarily sexist. As such they include jealousy [8] and the sense of control over the woman and her selfdetermination, reinforced by the patriarchal concept of the "owned female"2 [1], [9]. Unemployment, gun ownership, sexual extortion, substance addictions are mentioned as factors of impulse to femicide. At social level, factors include insufficient policing [4], (but also the frequently observed social inertia, justifying, though indirectly, the act. Finally, the unwillingness of the various legal systems to recognize the particularity of the crime and its sexist characteristics, reducing it to the generic term of homicide, although in some cases their attitude reaches the limits of misogynism, with the particularly low sanctions imposed encouraging the potential murderers [10].

\section{THE INTERNATIONAL EXPERIENCE}

Criminality targeting women is a reality that challenges civilization. High rates of murdered women are registered worldwide in descending order in Asia, Africa, America, Europe and Oceania ${ }^{3}$. What is clear is that the assessment of the dimensions of femicide is hindered by limited relevant data, since the relevant authorities (police, forensic authorities) do not usually investigate data such as the connection between the aggressor and the victim or the motives of the crime [4]. However, despite the objective difficulties in accessing the phenomenon, an interdisciplinary, systematic effort of its analysis, interpretation and eradication is currently ongoing [10], although it is being hindered also by the absence of a single measurable indicator with worldwide reliability. Individual data of each country are not comparable and cannot lead to safe estimations at regional or worldwide level regarding the total extent of the phenomenon [6]. However, it is worth noting indicatively that according to the World Economic Forum [11] and based on data of the United Nations Office on Drugs and Crime [6]:

- The annual number of murders of women is increasing ${ }^{4}$.

- Home is the most likely place where a woman can be murdered.

- Six women are killed every hour by men worldwide, mainly by men of their family or by their partners.

- More than half of the women and girls killed by men had a relationship with the aggressor, as he was their current or ex-partner ${ }^{5}$.

\footnotetext{
${ }^{2}$ Of course, in any case, every derogation from the legally established gender equality and from its substantial implementation [10] leads more easily to crime.

${ }^{3}$ Available international data confirm that the largest percentage of such murders occur in the family context, with Africa taking the lead, where women are more at risk than in any other place to be murdered by some member of their family [6].

${ }^{4}$ Latest UN data show that 137 women worldwide are murdered daily by their partner or a member of their family, while a total of 50,000 annually are murdered by people they know and trust [6].

${ }^{5}$ The highest number of all women globally murdered by people they knew, partners or family members in 2017 is identified in Asia (20,000). It is followed by Africa $(19,000)$ and America $(8,000)$, while lower numbers are observed in Europe $(3,000)$ and Oceania (300). It should be noted that regarding the percentage of femicides linked with a partner or family member, Africa holds the rate of 3.1 per 100,000 women, while it is the
}

\section{The PHENOMENON OF FEMICIDE IN GREeCE}

Also in Greece, femicide is characterized by common practices such as the cruelty of the criminal action, disappearance of the corpse, the aggressor's refusal to admit the crime [12], as well as the refusal of the legal system to accept the term "femicide" [13]. Femicides are usually intimate, accompanied in principle by the stereotype image, shaped also by the mass media, of a young man, who kills his partner mainly because of his jealousy, which is a result of her refusal to continue their relationship, image which is generally accepted. The fact is usually described in periphrasis: "he killed her because he loved her", "crime of passion", "criminal love" or even "unexpected love" [13], a fact that obfuscates preexisting inequality, violence, and sense of ownership in the intimate relationship and the aggressor's sexist motives.

Until 2018, in Greece there was no available data about the rate of femicides as a result of an aggression and the available quantitative data was related exclusively to the gender of the aggressor or the victim and the place of crime ${ }^{6}[13]$. In addition, there is no competent scientific authority in charge of collecting data and performing analyses using the criterion of the sexist, misogynist dimension of femicide [14]. Seeking the reasons for the way in which femicide is perceived by the Greek society and the gender-based collective awareness, we will insist that an important part of the responsibility lies with the dominant gender-based perceptions and representations, deeply patriarchal, reinforced in one or the other way by the mass media, which also intervene in the way of investigation of the phenomenon by the competent authorities and the justice system [1].

According to the $23^{\text {rd }}$ and $27^{\text {th }}$ "Briefing Note on genderbased violence" of the Observatory of the Secretariat-General of Family Policy and Gender Equality [15],[16] about femicides in Greece, some basic, although fragmentary, data become available. On the contrary, the data provided by the Greek Police ${ }^{7}$ are more concrete, informing about the following [14]:

- Every month a woman is murdered by some member of her family,

- During the period 2013-2018 a total number of 69 women were murdered as a result of domestic violence ${ }^{8}$. In 2019, in Greece 8 women were murdered by some member of their family, which leads to a percentage of $42.1 \%$ [16].

- Out of a total of 19 murders in the same year with female victims, 8 were femicides.

continent where women face the greatest risk to be murdered by a person they know, a partner or a member of their family.

6 However, followingtheratificationoftheIstanbulConventionin 2017), thePolicechangedtheway of recording the incidents of domestic violence, now recording the relationship between the aggressor and the victim as well as the type of domestic violence. Nevertheless, theassessmentofthephenomenonatnational $\quad-\quad$ andglobal levelisdifficulttoachieve, becauseofthesocial stigmatization of the victims and because of the prevalence social and cultural stereotypes, occurring also in most European Union countries. Thus, manyincidentsarenotdenouncedtothecompetent authorities [15]

${ }^{7}$ The Eurobarometer indicator measuring the level of trust of citizens in police for 2019 was $66 \%$ for Greece [15]; this confirms that many violence incidents remain undisclosed, as citizens hesitate to denounce them.

${ }^{8}$ They account for $30-50 \%$ of the total female victims of murders for the same period. 
Research led by [14] shows that:

- In 8 cases the couple was separated, or the woman had expressed her wish to separate, while in 4 cases previous exercise of domestic or family violence and the victims had denounced it to the competent authorities.

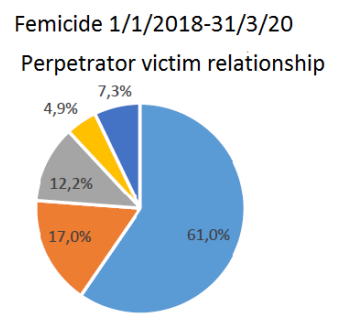

- Intimate-Partner = Another Family Member = known = Unknown = Non detection Fig.1Relationship between aggressor and victim of femicides in Greece [14].

- The motive of jealousy was often mentioned as a factor of the murders (in 12 cases), while the factors of alcohol and drugs were mentioned in 8 cases.

- Most femicides occurred in the provinces (percentage $68 \%$ ) and within the home (including all types of residences), which was the most common place of crime (percentage 78\%).

- The aggressors had a weapon, used it (in 12 cases), and when they did not have one, the often-used knives (in 12 cases), available tools (in 3 cases) and/or their hands, to hit, strangle or suffocate the victims (in 13 cases). In one case the man cut the woman into pieces and burnt her after the murder.

\section{Modus operandi}

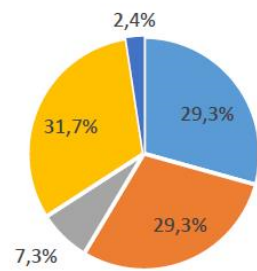

$$
\begin{aligned}
& \text { "Gun " Knife } \\
& \text { " Conducive Tool } \\
& \text { " Chopping and Burning }
\end{aligned}
$$

Fig. 1. Modus operandi of femicides [14].

- The average age of murdered women as well as the murderers is around 50 years, and more specifically 49 years for the victims (15 years old the youngest one and 87 the oldest one) and 51 years for the aggressors (20 years old the youngest one and 90 old the oldest one).

- In 3 cases the murder occurred following sexual aggression. In all 3 cases the aggressors tried to cover their tracks.

- The percentage of suicides and suicide attempts of the aggressors who had a family or emotional relationship with the murdered woman was relatively high (7 suicides and 3 attempts).

- 4 women out of 41 (percentage of approximately $10 \%$ ) in Greece were murdered by policemen/military officers, in service or retired, who possessed a weapon.

- 9 victims and 5 aggressors were of non-Greek origin.

- In all cases there was one aggressor, except in one case where there were two aggressors.

In any case, unfortunately also in Greece femicides are seen as family tragedies, "unfortunate moment" incidents and, often, instead of stigmatizing the aggressors and their sexist motives, the opposite occurs ${ }^{9}$. Therefore, the phenomenon and its sexist dimension are obfuscated, since the responsibility is shifted from the female killers to the victims, reality is not presented as it is, while the effort to rationalize criminal behaviors perpetuates the situation, leading to ever more extreme forms of femicide [17].

\section{CONCLUSION}

The consequences of a femicide are complex and multilevel, affecting the family, the community and the broader society [7]. A direct consequence is obviously the death of a woman because of her gender, but often the fact entails also long-term destructive consequences on the health, safety, personal and social life in the family environment of the victim and in particular for its underage members [10]. More specifically, we should not forget that the exposure of children at the hideous crime of femicide may be correlated with disorders or even future involvement of these children in acts of violence [7].

According to [16], the movement for recording cases of sexist and gender-based violence at panhellenic level, "femicides and attempts of femicide are recorded in the map with black tacks" while "in most cases these have been manifestly ignored by the competent authorities" and are underestimated by the mass media. Reference [14] confirms thebias of mass media, which use mainly commercial criteria to prioritize and promote news regarding crimes against women. They also unreasonably protect the allegedly "honest husband" or "protective" father; this is how the aggressor was presented in the case of AngelikiPetrou ${ }^{10}$. In this way, once again a great deal of the responsibility for the crime is attributed to the victim herself [9]. Finally, when the mass media present femicides with sexual motives, they often overestimate men's sexuality: when questioned by women and girls, it may lead to a crime ${ }^{11}$. The above manipulation from the press and its usual strategy to handle each case of femicide as an independent, individual incident [17], as well as the respective perception and practice of the legal system, prevent the recognition and handling of femicide as a hideous, sexist crime also in Greece.

undisciplined daughter, who ignored him, and consequently her disobedience led to crime.

${ }^{11}$ An indicative case is that of the murder of Eleni Topaloudi, student of the University of the Aegean. The aggressors were presented as super-male, emphasis was placed to their trained bodies and their virility, characteristics linked to their sexual impulses, which "reasonably" cannot be retained [18]. 


\section{REFERENCES}

[1] M. Gasouka, "Old history in modern context: Female infanticide/Femicide”. G. Petraki (ed.), Femicides. Findings, questions and question marks. Athens: Gutenberg, 2020b.

[2] Canadian Femicide Observatory for Justice and Accountability, (2020). The history of the term 'femicide', Accessed on 6/1/2021 from: https://www.femicideincanada.ca/about/history

[3] E. H. Russell, "Femicide: "Politicizing the killing of females". Strengthening Understanding of Femicide, 27, 2008.

[4] World Health Organization, "Understanding and addressing violence against women," 2012, Accessed on 12/12/2020 from: https://apps.who.int/iris/bitstream/handle/10665/77421/WHO_RHR_1 2.38 eng.pdf

[5] C. Kouta, E. Rousou, F. J. Freysteinsdóttir, S. Boira, M. Naudi, "Gender and socio-cultural perspectives through femicide case studies" J Community Med Health Care, 2(2), 2017.

[6] United Nations (2019). Global study on homicide 2019, Accessed on 6/1/2021 from: https://www.unodc.org/unodc/en/data-andanalysis/global-study-on-homicide.html

[7] M. C. Roa, R. C. Cordeiro, "Registration for a systematic review: Risk factors for femicide," The Campbell Collaboration, 2018.

[8] A. Tsouni, "Observatory for femicides: criticality, data analysis and proposals". G. Petraki (ed.), Femicides. Findings, questions, and question marks. Athens: Gutenberg, 2020.

[9] M. Gasouka, "Sociological approaches of gender. Questions of Power and Hierarchy," $3^{\text {rd }}$ edition. Athens: Diadrasi, 2013.

[10] C. Kouta, E. Kofou, A. Zorba, "Femicide in Greek-Cypriot and Turkish-Cypriot communities in Cyprus: A pilot study". Women's Studies International Forum, 77, 2019.

[11] Broom, D., (2020). As the UK publishes its first census of women killed by men, here's a global look at the problem, World Economic Forum, Accessed on 6/1/2021 from: https://www.weforum.org/agenda/2020/11/violence-against-womenfemicide-census/

[12] F. Milioni, "Femicide: Criminological and legal dimensions". In G. Petraki (ed.), Femicides. Findings, questions, and question marks. Athens: Gutenberg, 2020.

[13] S. Weil, C. Corradi, M. Naudi, "Femicide across Europe: Theory, research and prevention," Bristol:Policy Press, 2018.

[14] Kontochristou, A., (2020). A first comment on Femicide in Greece. Data analysis and drawing first concluctions, Accessed on 12/12/2020 from: https://www.aegean.gr/sites/default/files/static/20/07/elladagynaikoktonia.pdf.

[15] Secretariat-General of Demographic and Family Policy and Gender Equality - SGDFPGE (2019a). 23 ${ }^{\text {rd }}$ Briefing Note on gender-based violence.

[16] Secretariat-General of Demographic and Family Policy and Gender Equality - SGDFPGE, (2019b). 27 $7^{\text {th }}$ Briefing Note on gender-based violence.

[17] Sexharassmap, (2019). Femicide in Greece-Data and stories in the Media in 2019, Accessed on 6/1/2021 from: https://sexharassmap.espivblogs.net/2019/11/25/femicides-2019/

[18] M. Gasouka, (2020a). "When civilization recedes reflections on the phenomenon of femicide". Presentation at the seminar Violence against women: Practices of prevention and intervention during the pandemic, National Centre of Public Administration and Local Government, 25/11/2020 (unpublished).

[19] V. Artinopoulou, "Femicides: Conceptual and methodological issues," In G. Petraki (ed.), Femicides. Findings, questions, and question marks. Athens: Gutenberg, 2020.

[20] S. Vagena, "What is the role of Greek police in the issue of femicides?" In G. Petraki (ed.), Femicides. Findings, questions, and question marks. Athens: Gutenberg, 2020.

[21] A. Vougiouka, "Femicides: International experience, political dimensions and the transformation of silence into words and action," In G. Petraki (ed.), Femicides. Findings, questions, and question marks. Athens: Gutenberg, 2020.

[22] A. Michalakeli, "Femicide in public discourse and in the public sphere". In G. Petraki (ed.), Femicides. Findings, questions, and question marks. Athens: Gutenberg, 2020.

[23] G. Petraki, "Femicides are invisible murders". In G. Petraki (ed.), Femicides. Findings, questions, and question marks. Athens: Gutenberg, 2020.

[24] J. Brayton, M. Ollivier, W. Robbins, Introduction to Feminist Research, Policy, Action, Research List - PAR-L, 2020.

[25] L. Heise, M. Ellsberg, M. Gottmoeller, “A global overview of genderbased violence," International Journal of Gynecology \& Obstetrics, 78, $5-14,2002$.
[26] IM IS, AWOM. (n.d.). "When the Victim is a Woman," Accessed on $12 / 12 / 2020$ from: https://www.peacewomen.org/system/files/global study submissions/ GBAV2011 CH4 rev.pdf

[27] S. Swemmer, "Femicide and the Continuum of Gender Based Violence”. In: Leal Filho W., Azul A., Brandli L., Özuyar P., Wall T. (eds) Gender Equality, Encyclopedia of the UN Sustainable Development Goals, Springer, Cham, 2019.

[28] K. Royal, "It's like wallpaper': Victim-blaming, sexual violence and the media," Doctoral dissertation, Durham University, 2019. 